\title{
DEVOTIONAL DISCOURSE AND FEMALE AUTHORSHIP: FROM THE STEELE CIRCLE TO MARY WOLLSTONECRAFT
}

\section{Adina CIUGUREANU ${ }^{1}$}

\begin{abstract}
The article brings into discussion the case of a few exceptional women who wrote, published, and became popular in the Age of Reason as poets, critics, and activists. They were considered as Nonconformist because they belonged to the Baptist or Unitarian Church and did not follow the mainstream Church of England views. On the other hand, the end of the eighteenth century witnessed the rise of Romantic aesthetics and of a number of nature poets. The questions this article attempts to answer refer both to the influence of the Biblical discourse on a group of women's literary and non-literary productions and to the way in which the emerging Romantic aesthetics also impacted their work. How did devotional poetry go along Romantic principles and feminist views? Anne Steele's and Mary Steele's poetry, Mary Scott's and Mary Wollstonecraft's feminist agenda will be highlighted in the analysis.
\end{abstract}

Keywords: devotional poetry, literary circles, female poets, pre-Romanticism, feminist agenda

DOI: $10.24818 /$ SYN/2021/17/2.01

\section{Introduction}

Eighteenth-century women's interest in poetry, religion and politics, whether in this order or not, has been somewhat overshadowed in literary criticism by male authors, clerics and politicians. However, even in a patriarchal society as the eighteenth century was, women's voices were not completely muted, but allowed, within limits, to express their views concerning family matters, friendship, women's role and status in society, and, more specifically, Christian beliefs and devotion. Eighteenth-century poets followed a long tradition of religious poetry that started in the sixteenth century with John Donne and the other 'Metaphysical' poets and continued throughout the next century with John Milton's devotional epics. Women's writing, however, developed more slowly and was brought into light when knowing Greek and Latin ceased to be a man's privilege and when confessing to writing was no longer considered an indiscretion. The Age of Enlightenment was crucial in this respect. That was a new and fruitful time if we compared it with 'Judith' Shakespeare's age, so masterfully and emotionally described by Virginia Woolf in A Room of One's Own (1929).

As the eighteenth-century reading public accepted women as poets, volumes of poetic productions by women were added to individual poems published in the

\footnotetext{
${ }^{1}$ Adina Ciugureanu, “Ovidius” University Constanța, aciugureanu@univ-ovidius.ro
} 
major periodicals. Both received favorable reviews that openly revealed women's entrance in the selected circle of male writers. One such review printed on the occasion of the publication of Elizabeth Carter's volume, Poems on Several Occasions (1761) openly stated that ' $[\mathrm{t}]$ here never was perhaps an age wherein the fair sex made so conspicuous a figure with regard to literary accomplishments as in our own' because, while, in the past, "a reading and writing wife was considered a miracle', at present, '[1] earning is [...] grown so fashionable among all the ladies" (Longsdale (ed) 1984: xxxix). Although the point of the review was to praise the poetry of Elizabeth Carter, the tone reveals a patronizing attitude and an undisguised surprise at the discovery of a woman's genius.

In spite of the fact that literacy grew in the Age of Enlightenment, women's access to books in English or in a Classical language was limited to those belonging to the middle-classes, those who had the time to learn and to share their knowledge with their peers at informal dinners or in, what was called at the time, coteries or literary circles. Among these coteries, three seem to have become more prominent and to have produced important, though rather neglected, literature of all genres that developed topics ranging from nature, friendship, death/loss, women and society to devotion. Generally, the ladies belonging to these literary circles had a number of things in common: they were friends or related by family, they were middle- or upper-middle class, highly educated women, and were members of a specific Christian congregation. In all cases, their activity was both supported and supervised by clergy, male writers, and publishers.

\section{Women's Literary Circles or Coteries}

One such circle of women, called the Anglican Bluestockings, belonged to the mainstream Church of England. Hosted by Elizabeth Montagu and her friend Elizabeth Vesey, the literary, artistic and socially active women convened in London in the second half of the eighteenth century. A few notable names among them were Elizabeth Carter, Clara Reeve, Hannah More, Anna Seward, known for writing poetry, fiction, for their criticism and activism, mainly in the field of education for girls. Another one was largely known as the Coterie of Unitarian women and included the poet Anna Laetitia Barbauld, her niece, Lucy Aikin, Elizabeth Benger, and even the proto-feminists Mary Hays and Mary Wollstonecraft. (Whelan, 2015: 3) Because of Unitarianism, which most of the group members, their family and friends shared, they were looked at as Nonconformists, based on their rejection of Anglicanism and on the particular interpretation of the Holy Bible. ${ }^{2}$

\footnotetext{
${ }^{2}$ The Unitarians believe in God as a single entity, not as trinity (God the Father, God the Son, and the Holy Spirit) which is essential in other Protestant faiths, and also in Catholicism and the Greek Orthodox Church.
} 
The third literary circle, also labeled as Nonconformist, gathered around the Steele family and counted the Steele men, all Baptist Clergy, and three generations of women writers starting with Anne Steele, her niece, Mary Steele as leading figures, and including Mary Scott, Jane Attwater, Elizabeth Coltman, their friends and family. With the exception of Mary Scott who, at some point in her life, turned Unitarian, the other members of the Steele Circle were and remained Reformed Baptists (Whelan, 2015:11).

The women belonging to the three circles not only knew one another, but also had collaborative moments when they circulated manuscripts among themselves, edited each other's work or sent critical feedback, which, according to Margaret Ezell, is in opposition to the mediated popular Romantic beliefs that women writers lived in "isolation, alienation, and competition." (Ezell, 2002: 57) The bond among these women, the way in which they supported and influenced one another, how they tried to keep economic independence through writing and publishing, irrespective of the directions that each of them took (poetry, fiction, activism) is illustrated by their lengthy correspondence and diaries.

Not all these women wrote devotional poetry, though most of them did, and not all devotional poetry was published, some of it was preserved in manuscript form. Looking at their literary productions, the women of the Steele circle distinguished themselves as both promoters of faith, from which they never distanced, and poets of talent, managing to combine the 'spiritual' with the 'worldly' in a manner that is worth investigating. According to Timothy Whelan's description of the Steele circle, the women writers

embraced British culture, especially literary culture, yet never strayed so far from their faith that they could not apply spiritual lessons to their daily lives, combining faith and culture in their poems, letters, and diaries in ways that connect them with, while also distinguishing them from, Quaker, Methodist, and Unitarian women writers. (Whelan, 2015: 5)

It is probably the interest in reading, and commenting on, the Holy Book as a whole, not as passages or disconnected stories, as Calvin himself did all his life, that encouraged the women of the Steele Circle to turn the English version of the Hebrew Psalms into devotional poems and compose hymns and prayers. On the other hand, their most prominent representatives wrote poems about nature, friendship, loss, which exceeds the devotional theme and reveals an appetite for pre-Romantic and Romantic topics. Anne Steele, for example, who published under the name of 'Theodosia', became both the leading woman hymn writer of the eighteenth century and a known poet of worldly matters. Her published hymns, which became so popular that they are sung at church services even today (Watson, 1977: 101) explore, besides themes of "faith, grace, affliction, duty, death, heaven, and divine inscrutability", major tenets of Calvinism, such as "Imputed Righteousness, Justification, Sanctification, and the Trinity" (Whelan, 2015: 4) all in accordance with the Baptist faith and with, what was called at the time, 
Nonconformism. Yet, were the women of the Steele circle looked at as Nonconformist solely because of their faith or equally because of their education and interest in poetry and other literary productions? Formally, they were Nonconformist because of their faith, but I argue that their nonconformism exceeded the boundaries of religion and made them successfully embark on a writer's career which was largely the privilege of men. As writers, they behaved in conformity with their age: they published anonymously or under a pen-name or kept their literary productions in manuscript to be published posthumously. Yet, despite these constraints, they proved high competence and a strong desire of independence, subverting the common belief that they were less witted than, and inferior to, men.

It was very hard to find an established position in eighteenth-century culture as a Nonconformist man, let alone a woman. In his Culture and Anarchy (1869) Matthew Arnold looks at the Nonconformists as anti-Establishment clergy, who cannot reach perfection in culture because they fall short from attaining perfection in religion.

The great works by which, not only in literature, art, and science generally, but in religion itself, the human spirit has manifested its approaches to totality and to a full, harmonious perfection, and by which it stimulates and helps forward the world's general perfection, come, not from Nonconformists, but from men who either belong to Establishments or have been trained in them. (Armold, 1869: 4)

In Arnold's view, having deserted the Church Establishments cannot bring cultural or religious fulfilment and hinder the seekers of culture to reach "sweetness and light.' He calls the Non-conformists "provincial" and "philistines" and launches an appeal to their unification under the large umbrella of the Presbyterian Church. (Arnold, 1868: 4, 6, 9). What Arnold cannot see is that the Nonconformists, men and women alike, had no interest in defending the ivory tower of culture. On the contrary, their attention swerved to the lower classes in their continuous struggle to enlighten and educate them, to create opportunities for children to study and understand the Holy Scripture and for young girls to be able to read and write.

Therefore, I argue that the literary productions of the Baptist women of the Steele Literary Circle had a double purpose: on the one hand, the hymns and the rewriting of the Psalms of the King James Bible in rhyming verse and on musical notes were meant to instruct the others, to explain the spiritual things of the Holy Bible through poetry and music. On the other hand, despite the imagery and diction of the King James Bible, easy to spot in their works, their poetry combined the eighteenth-century diction, rhythm and metre with the sensibility of pre-Romantic aesthetics. 


\section{The Steele Women's Poetic Discourse}

\subsection{Anne Steele's Devotional Poems}

In what follows I will focus on the two directions described above: one, the analysis of the similarities and differences between two Psalms from the King James Bible and the respective versions offered by Anne Steele in her particular reading of them; two, the analysis of the Anne Steele's and Mary Steele's poetic productions as illustrations of pre-Romantic aesthetics that echoes William Wordsworth's Preface to Lyrical Ballads, in the 1800 edition.

Anne Steele published her first volume of poetry, Poems on Subjects Chiefly Devotional, under the nom-de-plume Theodosia, in 1760. Her penname, whose meaning in Greek is 'gift of God' or 'giver of God' suits the content of the volume which comprises, in its two parts, 106 hymns, 47 psalms, and a few 'occasional' poems on personal topics. The volume was so successful that a second edition was published posthumously in 1780, to which a third part consisting of miscellaneous poems was added. The edition was shortly followed by an equally acclaimed volume published in America.

Like a real devout, Anne Steel starts the first part of Poems with God praising hymns. God the Father and God the Son are glorified in various moments of the day and on various occasions, when the soul searches for happiness, for rest or is weary or joyful, melancholic or meditative. The display of emotion and the depth of sentiment are illustrated by phrases dedicated to God the Father and God the Son, such as: "Almighty Author", "Almighty Father", "the Great Sovereign of the skies", "Great Physician", "Great King of kings", "Great Ruler of the earth and skies", "my Maker and my King", "great advocate", "almighty friend", "comforter". The originality of Anne Steele's devotional vocabulary lies in her choice of metaphors, out of which only a few, such as Almighty, great King, comforter, had been borrowed from the Holy Scripture. "Great King", for instance, is to be found in a few places in the Bible, including Psalms 47, 48, 95. However, "Great King of kings" is Steele's intensified metaphor used in the hymn "Humble Worship":

GREAT King of kings, eternal God,

Shall mortal creatures dare to raise

Their songs to thy supreme abode,

- And join with angels in thy praise? (Steele, A. 1760, 1: 37)

Another one of the Biblical words, "comforter", may be found in the King James Bible in Samuel 10, Job 16, Ecclesiastes 4, Lamentations 2, Nahum 3, and Psalm 69 in negative constructions, meaning the absence of true "comforters" for those who need comforting. In the New Testament, however, in the Gospel according to St. John, the word is used by Christ to let the Apostles know that the Father will give them a Comforter ("And I will pray the Father, and he shall give you 
another Comforter", John XIV, 16). He is later disclosed, in line 26, to be the Holy Ghost ("But the Comforter, which is the Holy Ghost, whom the Father will send in my name", John XIV, 26). Jesus also continues to explain the role of the Comforter who "shall teach you all things, and bring all things to your remembrance, whatsoever I have said unto you"). The distinction between "no comforter" and the "Comforter" is made clear in the Holy Scriptures as a distinction between the 'old', the time before Christ, and the 'new', the time that will follow Christ's sacrifice as St. John describes it in the Gospel.

In her hymn, "The Influences of the Spirit of God in the Heart", which Anne Steele declares to have been inspired by John XIV, 16 and 17, she calls for God's Spirit (i.e. the Holy Ghost, but also the Spirit of Truth, that is Jesus Himself) to dwell in her "fainting heart" forever. The Spirit is described as a "Great spring of comfort, life, ... and light", a comforter who lives near ("nigh") the believing soul. Steele's optimistic belief that the Spirit will fill her heart is based on Christ's promise in John XIV that "I will not leave you comfortless; I will come to you" (17). Doubt does not exist in Anne Steele's hymns. To her, Christ is the "Comforter", the "Redeemer", the "Saviour", the "Physician of Souls" and also the "Great advocate" and the "almighty friend". While "redeemer" and "saviour" are repeated many times in the Old Testament, "Physician of Souls", "great advocate" and "almighty friend" are Steele's metaphorical names for Jesus Christ. They reveal, besides the poet's genuine devotion and creativity, her capacity of rendering the ideas of the Scriptures through accessible vocabulary to the common reader and daily church goer, which was one of the goals of the Calvinist/Baptist clergy.

Anne Steele's strategy of writing her hymns was to start from a line of the Old or New Testament, a line that must have impressed her very much. She then built on it, added rhyme and rhythm and turned it into a hymn. An example in this respect is the poem, "The Intercession of Christ", based on one line from Hebrews VII. In Paul's Epistle to the Hebrews, the Apostle describes Jesus Christ's mission to be a redeemer, to intercede for the absolution of people's sins ("Wherefore he is able also to save them to the uttermost that come unto God by him, seeing he ever liveth to make intercession for them", Heb., VII, 25). Anne Steele elaborates on this idea, by praising Jesus, who, "before his Father God, / Pleads the full merits of his blood". By doing this, He becomes the "great Redeemer", the "great advocate" and "almighty friend" who, "[a]bove our fears, above our faults, / His pow'rful intercessions rise, / And guilt recedes, and terror dies" (Steele. A., 1760, 1: 64-65). The poem grows from an intense expansion of the original line from the Epistle.

A very short line from the Corinthians ("For we walk by faith, not by sight"; Cor $\mathrm{V}, 7$ ) inspires Anne Steele to write the poem "Faith in the Joys of Heaven", in which she elaborates on "faith' that brings "joys beyond the sky" and on the common use of 'sense' (her interpretation of 'sight') which "can but furnish scenes of woe, / In this low vale of tears", where "No groves of heav'nly 
pleasures grow, / 'No paradise appears." (Steele, A. 1760, 1: 70). The poem is structured on the opposition between faith (heart) and sense (reason), which is Steele's personal interpretation of the original word used in the Corinthians.

Grounded on Descartes's dualism, the opposition 'heart' versus 'mind' is basic in eighteenth-century philosophy and lies at the core of eighteenth-century thought. John Locke and David Hume, on one side, Spinoza and Kant, on the other, discuss the existence of mind and body and its effects on humanity in general, religion, politics, and society in particular. Contrary to the different, approaches to the body-mind duality by philosophers, devout Christians, whether Conformists or not, question the body-mind opposition when it comes to belief in God and salvation by Christ. Neither can exist by itself and neither is more valued than the other. Therefore, mind and body (reason and heart) should coexist and support each other in man's attempt to ascend to heaven. Anne Steele shares this view, because, as she affirms in her poem, it is the heart that drags the "erring mind" and it is passion ("celestial ardour") that reveals, to both sense and faith, the joys of heaven.

Most of the eighteenth-century poets tried their skill at turning passages from the Holy Bible into odes or hymns, besides indulging themselves in writing odes on Fancy and satires on mundane (London) life. There was little difference between 'translating' and 'paraphrasing' in the eighteenth century, both terms sharing a similar meaning. While 'translate' meant 'carry across' languages and cultures (Lat. translatio), 'paraphrase' denoted the action of 'translating loosely' (Gr. paraphrasis) according to Samuel Johnson's definition of the word. (Morris, 1974: 104-114). Considering that hymn writers and psalmists started from an already translated text, 'paraphrase' was the official term used by both men and women poets. However, the difference between them lay in the strategies used in 'paraphrasing'. Whereas to male poets and psalters it was a mere exercise to rewrite, usually famous, passages from the Bible in poetic form with rhyme and metre, to female poets, 'paraphrasing' meant elaborating on the biblical text, an action that required high poetic creativity. An example of 'paraphrasing' as 'rewriting' into rhyme and metre could be found with any psalmist who accommodated the Psalms of the King James Bible into versions to be recited or sung in church.

One such version, very popular throughout the eighteenth century in the Anglican church, was Nahum Tate and Nicholas Brady's A New Version of the Psalms of David in Metre, published in 1696. The two psalmists stuck not only to the meaning of the initial text, but also to the vocabulary, which they used in their version as much, and as often, as possible. Thus, for instance, the paraphrase of Psalm 1 of the King James Bible follows the content of David's translated text that offers the reader three suggestive poises of the faithful: keeping the right path, observing, and meditating on, the law of God, and living on God's words just as a tree planted by the river lives on water. The same ideas and the same images, 
described in words that an eighteenth-century church goer may understand more easily, are found in Tate and Brady's version.

Women psalmists, on the other hand, were more imaginative when 'paraphrasing' the biblical text. They religiously followed the structure of the psalms, generally based on synonymous parallelism, like the psalm under discussion, but they also looked for poetic devices (metaphors, epithets, personifications) and more modern vocabulary to render the meaning of the original text. Paula Backscheider calls these women poets, among whom I would certainly include Anne Steele, 'the voice of paraphrase' (Backscheider, 2005: 126-137) due to their extraordinary resourcefulness when adapting the Psalms to eighteenth century grammar and vocabulary. To her, women psalmists do not simply 'paraphrase', which they claim to do in all modesty, but they give 'paraphrasing' a particular voice. The second volume of Steele's Poems on Subjects Chiefly Devotional, for example, contains 47 'paraphrased' psalms, out of the 150 of the Book of Psalms. Comparing the first half of Psalm 1 of the holy text with Steele's Psalm the First, the poet's creativity, her way of embellishing the text with poetic devices becomes immediately noticeable.

Psalm 1

King James Bible

1 BLESSED is the man that walketh not in the counsel of the ungodly, nor standeth in the way of sinners, nor sitteth in the seat of the scornful.

2 But his delight is in the law of the LORD; and in his law doth he meditate day and night.

3 And he shall be like a tree planted by the rivers of water, that bringeth forth his fruit in his season; his leaf also shall not

wither; and whatsoever he doeth shall prosper.
Psalm the First

Anne Steele

1. Happy the man, whose heav'ndirected feet

Avoid the crowded path where sinners meet;

Who shuns the lofty seat of impious pride;

Of men, who dare Jehovah's law deride.

2. He in the sacred, venerable law,

(Inspiring holy thoughts and pious

awe,)

Continual meditates with new delight;

Guide of this day, and solace of his night!

3. Beneath heav'n's kindest influence he shall grow,

Like a fair tree where cheering waters flow;

Whose grateful boughs confess the happy soil,

And crown'd with autumn's richest bounty smile.

(Steele, A. 1760, 2:131) 
In her version, a happy man has 'heav'n directed feet', a reference to Judgment Day, when God will separate the pure from the sinful. Man and nature intertwine: the happy man grows, like a tree, 'beneath heav'n's kindest influence' and confesses the 'happy soil' (meaning both roots and grave) while waiting for Judgment Day, when he expects to be crowned (the crown of a tree, the crown on a man's head) and rewarded with a smile. The richness of the metaphors and personifications creates the image of a regained Paradise.

Steele's general strategy as a psalm rewriter is to use the entire version of the Authorized Text as a starting point for her own version. However, at times, she chooses only a few verses of a Psalm and fills in the free space left unoccupied with her own ideas and images that she wants to convey through the poem. Psalm 137, for example, one of the most popular of the Holy Book, best known as "By the Rivers of Babylon", refers to the forced exile of the Israelites to Babylon, after Jerusalem was destroyed. The psalm has nine lines, divided into three unequal parts: lines 1-4 describe the hard life of the people who have to live on an alien land and their reticence to play the harp for the oppressor, lines 5-6 are an ardent admonition to those who might forget their beloved city, Jerusalem, and lines 7-9 are filled with images of prophetic, violent revenge.

Anne Steele elaborates her poem on the core ideas of the Psalm: the hapless fate of the exiles, a self-admonition, and a prophetic retribution day. She develops the ideas in 12 stanzas, with a strong focus on the fate of the exiles, who are not Babylon's slaves, but reside in Babel: "Where Babel's rivers winding stray / A silent, cool retreat we chose". By opening her poem with Babel instead of Babylon, she addresses all the peoples who got 'exiled' from Mother tongue in their attempt, and impunity, to reach God. Returning to the fate of Sion, she mourns for the Israelites' grief and "streaming eyes" and deplores the "wretched, ruined state." The apocalyptic vengeful scene at the end is replaced with a moment of atonement, when God forgives Babel for trespassing the law ("sure reward awaits thy guilt") and an image of vengeance which is so strong that it hurts the eye:

Happy the man who then shall rise,

(While heav'n the righteous vengeance owns,)

And dash with unrelenting eyes,

Thy bleeding babes against the stones.

(Steele, A. 1760: 228-230)

The combination of forgiveness and retribution fits into the image of the Apocalypse of the New Testament rather than into the actions of God the Father of the Old Testament who is known to be more vengeful and less forgiving than God the Son, whose mission was to bring peace, love and forgiveness.

Like most Nonconformist poets' mission, Anne Steele's was to "edify, instruct, enlighten and inform others in the knowledge of spiritual and heavenly things" (Whelan, 2015:17). Enlightening through poetry was, to her, a major component of 
'instruction'. Yet, she did it not only through versification and the use of metre, but also through 'autochthonization', the rendering of biblical subjects into eighteenthcentury easily detectable and understandable imagery. Her devotional poems are not 'unadorned' like the Calvinist/Baptist chapels, nor are they a 'plain', succinct picture of human spirituality, as Donald Davie claims (Davie, 1993: 25). They fuse, what Davie calls, "simplicity, sobriety and measure" (25) with restrained passion, a visible characteristic of pre-Romantic sensibility. It is this restrained passion and Steele's inclination towards isolation and retirement in nature that are associated with pre-Romantic poetry. Anne Steele's nature poems pave the way to Wordsworth and Coleridge's Romantic aesthetics, with a focus on feeling, on the aroused emotion. Her poem "Spring and Autumn", for instance, is an example of meditation on the transitory aspect of life, both natural and human, which, badly managed, may reveal "blossoms" that "only serv'ed for show".

\section{When Spring her various sweets, And op'ning blossoms cheer the eyes, And fancy ev'ry beauty meets, Whence does the pleasing transport rise? \\ Soon will their transient date expire, They fly and mock the fond pursuit; New pleasures then the thought inspire, And bounteous autumn yields her fruit.}

(Steele, A. 1760, 1:29)

In most of her secular poems, Steele longs for solitude, retirement and meditation, which brings her very close to spirituality and devotion. She calls for solitude as the Romantic poet calls for the inspiring Muse: "Kind Solitude, I love thy friendly shade" ("Retirement and Solitude") and "Softly -pleasing Solitude, / Were thy blessings understood" ("Solitude"). Solitude and retirement coupled with meditation reveal, on the one hand, the innermost beauties of nature, and, on the other, the path that leads to revelation and complete devotion of God.

\subsection{Mary Steele's Sensibilities}

While Anne Steele was, and still is, acclaimed for her religious poetry, for her hymns and psalms, her niece, Mary Steele (1753-1813), wrote poems that are much closer to pre-Romantic aesthetics besides conveying nonconformist ideas as regards society and education. She was one of the members of the Steele Circle, more involved in activism, politics, and feminism than her much acclaimed aunt.

Mary Steele's poetry combines the theme of isolation and retirement with feminist sensibility about the equality of sexes. Her nom de plume is Sylvia, or Silvia, meaning 'forest' or 'woods' in Latin, which sends the reader of her poems to the theme of nature, highly cherished by the poet. To Sylvia, nature invited to solitude 
and reflection, as it did with her aunt, but as opposed to her aunt's deep and complete devotion that nature enhances, she found in nature a secluded place which she could share with her female friends. Mary Steele cherished the woods at her uncle's estate at Yeovil, where she often went for strolls, especially in the company of the fellow-poets Myra (Mary Scott) and Celia (Miss Williams) to whom she dedicated a few poems. The "beauteous sylvan scenes around", in which her "feet" learned "to stray" with Myra and Celia offer Mary Steele the opportunity to muse about her very dear friendship with the two fellow-poets and crave for their presence, by her, for the stroll (“A Rural Meditation”, 1766).

Two of her poems, "The Rustic Maid" and "Rural Pleasures", both composed in 1771, reveal the poet's love for nature and solitude, the themes that prefigure Wordsworth's Preface to the 1800 edition of the Lyrical Ballads in which he foregrounds "humble and rustic life" as the chief subject of the volume, "because in that condition of life our elementary feelings coexist in a state of greater simplicity" (in Brett \& Jones eds. 1991:236). To 'Sylvia', rural life, quiet and "[r]emote from Hurry, Noise and Strife", makes the perfect scene in which the Nymph (i.e. the maid) walks unseen in "Solitude" and "Peace", far from any Lordly Man's "guileful plan" of betrothal. That uninvaded space, undisturbed by "lordly Husband's frown" or marital discord, undeceived by any "broken Vow", makes "Virtues bloom / within the rural Maiden's breast", while "Unseen, Unknown she struts thro' time" and, "wafted to a happier Clime, / She blooms beyond the reach of Scorn" (in Whelan, ed. 2011, 3:72-73). The poem entwines nature, solitude, and rural life, with a nonconformist attitude toward marriage, which, in Mary Steele's opinion, ruins the woman's freedom of action and of mind. Though Wordsworth's "low and rustic life" was meant to describe the life of the lower classes in the countryside, Mary Steele's image of rustic life conforms to Wordsworth's vision that, in the situation of 'rustic life' "the essential passions of the heart find a better soil" (in Brett \& Jones eds. 1991:236).

Mary Steele's "passions of the heart" include, besides nature worship, strong feelings of friendship for her aunt, "[t]hat dearest bliss, the Converse of a Friend", and her circle of female poets, whom she kept very close to her heart. In "Rural Pleasures" (1771), the rural scene, with "[t]he new mown Hay dispensing sweets around" and the "rural Landscape" still "pleasing" in winter seem to be innocent pleasures in which "Simplicity displays her Charm" (in Whelan, ed. 2011, 3:7172). They are, in fact, strong passions of 'a simple Maid' who calls for the "gentle rural Muse" to lend her "Aid" and "bid this Bosom glow with vital fire!". While she enjoys this "unpolished Lay" (i.e. landscape) and devotes it to "Friendship's generous flame", she disregards "Ambition's fleeting form" and asks for "Nature's beauties to explore". Retirement in nature close to her friends and aunt, Theodosia, is enough to make "Virtue and Content this bosom warm" and worship "Nature's bounteous Lord", who, in this context, refers to God. The spiritual Father, less demanding and oppressive than the earthly man, thus replaces the Lordly Man of "The Rustic Maid". 
Mary Steele's vision of feminine and masculine corresponds to the image of virtues that intertwine in, what Whelan calls, an 'androgynous spirituality' (Whelan, 2015: 57). She strongly believes in the equality of the sexes and, if marriage and domestic duties hinder a woman's desire to write poetry, then the marital contract should be rejected, because it obstructs woman's freedom to develop her in-born artistic gifts. Her dedication to a life of poetry writing made her postpone her marriage until an age beyond the usual one for starting a family. Mary Steele's attitude concerning marriage may have been influenced by the two important revolutions of her time: American and French. Both enflamed the spirit of the young generation of men and women alike. The Steeles and their friends (like the Attwaters, whose young members, Jane and Marianne, also wrote poetry) were opposed to the war against the American colonies and were convinced that individual liberty and religious tolerance were worth fighting for. Just as they sided with the American colonies, they also tacitly supported the French revolutionary ideas and, although they were opposed to the war against France, they later became disillusioned with Napoleon's wish to become a dictator. To the Nonconformists, especially for the Baptists, the French Revolution fit into the biblical paradigm of "liberation from bondage" (Prickett, 1996: 157-158). Nonconformism was, therefore, not only a religious dissent, it was also sharing anti-establishment attachments and progressive principles such as liberty, equality and brotherly love (in Whelan, ed. 2011, 3: 45-46).

\section{Mary Scott, Mary Wollstonecraft, and Early Feminism}

Against this background, feminist ideas blossomed. In the Steele Circle, they first started with Mary Steele's theme of the woman-poet as independent rustic maid, a lover of nature's beauties and of solitude, which, according to her, was the sole provider of intellectual, emotional, and spiritual satisfaction. To this, she clearly opposed the vanities of society, in general, and of conventional marriage, which she described as a cage, in particular. Her own marriage occurred when she was 43 years old, an unusually old time for the first marital contract at the time. Through her poetry she exposed her ideas of human love, whether between a man and a woman or between two women (Whelan, 2015: 76). True love, she considered, did not depend on biological sex. To prove her creed, she wrote and published the poem Danbury; or the Power of Friendship, a Tale (1776), which she dedicated to her friend Mary Scott ('Myra'). In her 'tale', composed in pentameter form and set in medieval times, she describes death as the utmost sacrifice a woman is capable of to prove her love for her female friend.

Mary Scott, who shared Mary Steele's views on nature, solitude and friendship (she also postponed marriage as much as possible and seemed to be deeply unhappy with the marital status), was a strong voice in support of women-poets. When John Duncombe, an Anglican priest, published The Feminead or the Female Genius in 1757, in which he praised 15 British women writers from the reign of 
Charles II to mid-eighteenth century, Mary Scott felt the need to write a response: The Female Advocate (1774). It took her almost twenty years to write and publish the long poem, but its feminist message has lasted through centuries. She not only added to Duncombe's list of 15 women another 35 and came up with 50 names of women poets from Henry VIII's last wife to the present, but she also described the achievements of the British female poets from a woman's perspective.

Duncombe's praise of female poets has a strong patriarchal tone. The speaker addresses "lordly Man" who is invited to praise "the Sex [he] love[s]" and to tell how "adorn'd with every Charm, [women] shine, /In Mind and Person equally divine, / Till Man, no more to Female Merit blind, /Admire the Person, but adore the Mind (Duncombe, 1757: 4, 1l.11-14). Woman is referred to in these lines as if she were an object, a thing of art, whose merits have been discovered lately and who, at times, reveals more than the mere exterior aspect, in which case Man may start to "adore the Mind". The speaker seems to have been surprised by the discovery of female genius and, though he praises woman for her artistic talent, he advises her to "employ by Turns the Needle and the Pen" (1. 357). It is probably this patronizing description of woman that Mary Scott felt it did not conform to reality, besides the short list of talented female poets that Duncombe produced. Although she praises him for writing about women, she cannot help noticing his infatuated shortsightedness. Therefore, she reacts to The Feminead by writing a 522 line-long poem (compared to the 320 lines of Duncombe's) in which she praises 50 women, including both Renaissance female authors and recently published writers like her close friend, 'Theodosia', and the Black servant and former slave, Phillis Wheatley.

In the Preface to The Female Advocate, Mary Scott gives a brief analysis of the current state of facts, regarding the case of women in a patriarchal society. She wonders how much men know about "the distinction of sexes in souls, of the studies, and even of the virtues proper for women." (Scott, 1774: vi). She acknowledges the fact that women have been allowed by men to study "the imitative arts", but they are still prohibited "from cultivating an acquaintance with the sciences" (vi). Moreover, a woman whose "faculties" are left "to rust" is seen with "a more favorable eye" than the one who engages in the search for truth. She pleads for women to have access to general education and to be offered the opportunity to read literature, which will improve "their minds in useful knowledge", in the "leisure hours", if they are not talented enough to write (Scott, 1774: viii). The two concepts of enlightenment and education are general pursuits on the Nonconformists' agenda. To them, the women of the Steele Circle have added their claim for equal rights between the sexes as regards education as a compulsory path to mind improvement. Mary Scott's deep, passionate concern about the inequality of the sexes is expressed in her wish that "a time may come, when men will be as much ashamed to avow their narrow prejudices in regard to the abilities of our sex, as they are now fond to glory in them" (vii). Her undisguised critique of Duncombe's haughty attitude is revealed in her wish.

Mary Scott was encouraged in her poetic career and in the publication of The Female Advocate by William Steele IV, Mary Steele's father ('Philander' in the 
poem), a 'lordly Man' whom she praises for his open-mindedness and thanks for his continuous support of her poetic achievements.

\begin{abstract}
PHILANDER! Generous, affable, sincere, His taste as polish'd as his judgment clear, Blest with the tenderest feelings of the Heart, Wise without Stiffness, prudent without Art.
\end{abstract}

(Scott, 1774: 39, ll. 489-492)

He must be one of the men who will not have to be "ashamed for his narrow prejudices" in the future. As a Nonconformist, he was a man who encouraged the women of the Steele Circle to celebrate the essential doctrines of eighteenthcentury Baptism. The importance of family and practice of religion within it, the recognition of the natural world as representative of spiritual values, the power of prayer as well as an appreciation of England's civil and religious liberties are only a few of the virtues that he taught his daughter, Mary Scott, Jane Attwater and their female friends. These are some of the ideas that they use in their poetry whether religious or secular. Mary Scott, for instance, celebrates them in both her hymns and in the religious composition in verse, Messiah. A Poem (1788). Schooled by Anne Steele, Scott's hymns composed before the publication of The Female Advocate reflect her mentor's Calvinist/Baptist views, a faith she shared with her family and friends in the Steele circle before her movement into the Unitarian church the following decade. This could probably be the reason why manuscript copies of her hymns that circulated far beyond the Steele circle got lost. (Whelan, 2015: 109)

Returning to her feminist view on the necessity of women's education, it predates Mary Wollstonecraft's similar comments in A vindication of the Rights of Woman: with Strictures on Political and Moral Subjects (1792). A Unitarian herself, Wollstonecraft writes the feminist manifesto as a response to the French Catholic Bishop and Minister, Talleyrand-Périgaud's report on public instruction, presented to the National Assembly of France in 1791. Wollstonecraft' s Vindication is an essay in which she heatedly argues for women's rights in the British society. "My main argument", she writes, "is built on this simple principle, that if [woman] be not prepared by education to become the companion of man, she will stop the progress of knowledge and virtue", which will affect the children's education as well (Wollstonecraft, 1796: vi). She develops this argument in 13 chapters, out of which Chapter 12 is dedicated to public education, while the last chapter draws general conclusions to the entire essay. Among the revolutionary ideas, which Wollstonecraft introduces, two distinguish themselves: education for women and mixed day-schools for boys and girls. Women, according to Wollstonecraft,

have been allowed to remain in ignorance, and slavish dependence, many, very many years, and still we hear of nothing but their fondness of pleasure and sway, 
[...] their childish attachment to toys, and the vanity that makes them value accomplishments more than virtues. (Wollstonecraft, 1796: 385)

To her, this state of woman is unproductive because it does not lead to the preservation of morality in the society. Virtues are developed through general education, not only through religion and recitation of texts without understanding them. Education should be organized in national establishments, not in boarding schools, in which the child lives far from his or her parents, or at home, where the child is unable to socialize with children of his/her generation. Established in mixed day-schools, Wollstonecraft argues, "the constitution of boys would not be ruined by the early debaucheries, which now make men so selfish, or girls rendered weak and vain, by indolence, and frivolous pursuits" (Wollstonecraft, 1796: 390). By growing and developing together, boys and girls establish an equality between the sexes, which would allow friendship to grow and "love to temper the heart for the discharge of higher duties" (390).

Unlike Mary Scott, for whom friendship is unlimitedly sacred and utterly divine, Wollstonecraft regards friendship as a social interaction, an emotional bond between same-sex or mixed sex individuals, based on the shared memory of school years. While Mary Scott's view on the liberty and progress of women is both religious and aesthetic, according to her belief that more women should develop their artistic skills, write and publish, Wollstonecraft looks at women from social and political perspectives and foregrounds their role in the society and family for the advancement of learning.

\section{Conclusion}

Contrary to Matthew Arnold's opinion that Nonconformism had negative effects on the church and society, because of its Philistinism and anti-Establishment attitude, the Calvinists/Baptists (the Steeles and their circle) and the Unitarians (Mary Wollstonecraft and Mary Scott, towards the end of her life, among others) contributed to the enhancement of British culture in the eighteenth century. Being educated and creative they were very active in the literary and cultural life at the time by reading, editing, sharing, criticizing, commenting on, and responding to, men and women writers' poetic or fictional works. While the Baptist women became famous for their devotional poetry (odes, hymns, psalms) as well as for their secular writings, the Unitarians got involved in the women's "cause" and fought for a change of the old prejudice concerning the (in)equality of the sexes. Besides struggling to maintain an economic independence as writers and to change the views regarding the marital status considered to be the only way for a woman to attain achievement in life, they also expressed a deep sensibility in their writings, prefiguring early nineteenth-century Romanticism. In their poetic and religious discourse, they managed to create an "imagined community" (Kelly et al. 1999: xxiv) of women writers whose talent and dedication paved the way for nineteenth-century women's artistic achievements and stronger feminist views.

SYNERGY volume 17, no. $2 / 2021$ 


\section{References and Bibliography}

Arnold, M. 1869. Culture and Anarchy, Blackmask online, 2001. Retrieved from https://www.blackmask.com. Accessed on 20 November 2020.

Backscheider, P. R. 2005. Eighteenth-Century Women Poets and Their Poetry (Inventing Agency, Inventing Genre), Baltimore: The Johns Hopkins University Press.

Benson, L. F. 1915. The English Hymn: Its Development and Use in Worship. London: Hodder and Stoughton.

Brett, R.L., Jones, A.R. (eds). 1991. Wordsworth and Coleridge: Lyrical Ballads, London, New York: Routledge.

Davie, D. 1993. The Eighteenth-Century Hymn in England. Cambridge: Cambridge University Press.

Duncombe, J. 1757. The Feminead: or, Female Genius. A Poem. $2^{\text {nd }}$ ed. London: Printed for $\mathrm{R}$ and J. Dodsley. Retrieved from https://books. google.ro/books?id=g7ohAQAAMAAJ\&printsec=frontcover\&hl=ro\&sour $\mathrm{ce}=\mathrm{gbs} \_g e \_s u m m a r y \_r \& c a d=0 \# \mathrm{v}=$ onepage $\& \mathrm{q} \& \mathrm{f}=\mathrm{false}$. Accessed on 6 May 2021.

Ezell, M. J. 2002. "The Posthumous Publication of Women's Manuscripts and the History of Authorship", in Women's Writing and the Circulation of Ideas: Manuscript Publication in England, 1550-1800. Justice, G. L. and N. Tinker (eds), Cambridge: Cambridge University Press, pp. 121-136.

Franklin, C. 2015. "Enlightenment Feminism and the Bluestocking Legacy", in The Cambridge Companion to Women's Writing in the Romantic Period, Looser D. (ed.), Cambridge: Cambridge University Press, pp. 115-128.

Kelly, G. (gen. ed). 1999. Bluestocking Feminism: Writings of the Bluestocking Circle, 1738-1785. London: Pickering \& Chatto, Vol 1.

Keeble, N. H. 1987. The Literary Culture of Nonconformity in Later SeventeenthCentury England. Athens, GA: University of Georgia Press.

Lonsdale, R. (ed.). 1984. The New Oxford Book of Eighteenth-Century Verse. Oxford: Oxford University Press.

McGrath, A., D. C. Marks (eds). 2004. The Blackwell Companion to Protestantism, Oxford: Blackwell.

Morris, D. B. 1972. The Religious Sublime: Christian Poetry and Critical Tradition in $18^{\text {th }}$-Century England. Lexington, KY: University of Kentucky Press.

Pohl, N. and B. Schellenberg (eds). 2003. Reconsidering the Bluestockings. San Marino, CA: Huntington Library.

Prickett, S. and R. Carroll (eds). 1998. The Bible. Authorized King James version with Apocrypha. Oxford and New York: Oxford University Press.

Prickett, S. 1996. Origins of Narrative. The Romantic Appropriation of the Bible. Cambridge: Cambridge University Press.

Scott, M. 1774. The Female Advocate; a Poem. Occasioned by Reading Mr Duncombe's Feminead. London: Printed for Joseph Johnson. Retrieved 
from $\quad$ https://books.google.ro/books?id=jaVYAAAAcAAJ\&printsec $=$ frontcover\&hl=ro\&source $=$ gbs_ge_summary_r\&cad $=0 \# \mathrm{v}=$ onepage $\& \mathrm{q} \& \mathrm{f}$ =false. Accessed on 23 May 2021.

Steele, A. 1760. Poems on Subjects Chiefly Devotional (in two volumes) by Theodosia. London: Cornhill.

Tate, Nahum and Brady, Nicholas. 1698. A New Version of the Psalms of David in Metre, London: Published by M. Clark. Retrieved from

https://static1.squarespace.com/static/5b11858da2772cf01402ee6e/t/5d700a4e4e26 b8000133da3d/1567623778798/NewVersionofthePsalms1698-Clark.pdf. Accessed on 3 May 2021.

Vlad, E. 2004. Romantic Myths, Alternative Stories. Constanţa: Ex Ponto.

Watson, J. R. 1977. The English Hymn: A Critical and Historical Study. Oxford: Clarendon Press.

Whelan, T. 2015. Other British Voices: Women, Poetry, and Religion, 1766-1840. New-York: Palgrave Macmillan.

Whelan, T. (gen. ed.). 2011. Nonconformist Women Writers, 1720-1840, London: Pickering \& Chatto, vol. 3.

Wollstonecraft, M. (1796) 'A vindication of the Rights of Woman: with Strictures on Political and Moral Subjects', London: Printed for Joseph Johnson, $3^{\text {rd }}$ edition. Retrieved from http://library.um.edu.mo/ebooks/b33216423.pdf. Accessed on 10 June 2021.

\section{The author}

Adina Ciugureanu is Professor Emerita of English and American Literature at "Ovidius" University Constanța, Romania. She was the Dean of the Faculty of Letters between 2004-2012 and Director of the Institute for Doctoral Studies between 2016-2019. Her major interests range from nineteenth and twentieth century British literature to American modern fiction and poetry and popular culture. She has had numerous research grants to prestigious institutions such as Cambridge University (1996, 2002), Oxford University (2006), Baylor University (Armstrong Browning Library, 2007) a Fulbright Scholar grant to UNLV, Nevada (2001-2002) and a second Scholar grant at UCSB, California. Among her publications, mention should be made of Victorian Selves (Constanța: Ovidius University Press, 2004, revised version in 2008), Modernism and the Idea of Modernity (Constanța: Ex Ponto, 2004, republished in 2008), Post-War Anxieties (Constanța: Ex Ponto, 2006), The Boomerang Effect (Constanța: Ex Ponto, 2002), revised, translated into Romanian, and published in 2008 as Efectul de bumerang (Iași: Institutul European). She has also published over 30 articles and essays in national and international volumes and journals, edited and co-edited 9 conference volumes (among which National and Transnational Challenges to the American Imaginary, Peter Lang, 2018 and Ideology, Identity and the US: Crossroads, Freeways, Collisions, Peter Lang, 2020) and had numerous participations in international conferences, including key-note addresses. Currently, she is working on a study on cityspace and its representations in British, American, and Romanian fiction. 